\title{
The Defeat of the Invincible Armada: A Myth or a Reality?
}

Petraq Buka Assoc.Prof.

\author{
Tirana University, Albania
}

\section{Doi:10.5901/jesr.2013.v4n3p33}

\section{Abstract}

Covered in a mist of myth and legend, the story of that summer in the Channel drifted farther and farther from reality. Its actual results were distorted and misstated. There was a long period of uneasy peace and cold war before the actual outbreak of major hostilities. Most English historians have been certain that Elizabeth should have gone to war with Spain long before she did and have blamed her for weakness and reluctance to spend money. The leading Puritans blamed her stubborn refusal to subsidize Protestant leaders on the Continent. No ruler of this century was more sensitive to the economic interests of the country than Elizabeth. By the early 1580's the drift toward war in both countries was becoming irresistible. But neither King Philip nor Queen Elizabeth believed that war was inevitable. They both refused to the last moment to take the step of an open declaration of war. They both wanted to preserve a semblance of peace between their two countries. There were, however, strong arguments for peace. Modern historians have cited the Spanish monopoly of the American trade as a cause of the war.

Keywords: armada, gunpowder, cannonballs, harbour, repulse, fleet

No event in England's military history, not even the battles of Trafalgar and Waterloo, not even the battle of Hastings, has been so much written about and commented upon as the repulse of the Spanish Armada by English naval forces after nine days of dubious battle in the summer of 1588. The repulse foiled the Spanish plan to invade England with the Duke of Parma's[1] army in the Netherlands, supported by a Spanish fleet. English writers and historians hailed the victory as a sign of God's favour to the champions of the Protestant cause.

Wrapped in a mist of myth and legend, exaggeration and faulty judgment, the story of that summer's week in the Channel drifted farther and farther from reality. Its actual episodes and results were distorted and misstated. When scholars began to work from the archives, gradually the mist was dispersed. But even the most careful scholar may find himself trapped by a tale he has always believed. By now, through the efforts of Spanish and English historians, most of the mistakes about the Armada campaign and the Anglo-Spanish naval war have been corrected.

There was a long period of uneasy peace and cold war before the actual outbreak of major hostilities. Most English historians have been certain that Elizabeth should have gone to war with Spain long before she did and have blamed her for weakness and reluctance to spend money. The leading Puritans accused the Queen of vacillation, blamed her stubborn refusal to subsidize Protestant leaders on the Continent and her belief that peace with the armies of Anti-Christ could still be preserved. On the other hand, the condemnation of Philip II's[2] policy as cold, sluggish, and timid has tended to mount. A Spanish historian is of the opinion that the King 'should have stamped out the nest of vipers across the Channel before they were strong enough to bite his heel'.

The Pope himself and the Jesuits called for a holy war for the deposition of the heretic Queen. By the early 1580's the drift toward war in both countries was becoming irresistible. But neither King Philip nor Queen Elizabeth believed that war was inevitable. They both refused to the last moment to take the step of an open declaration of war. They both wanted to preserve a semblance of peace between their two countries.

There were, however, strong arguments for peace. Modern historians have cited the Spanish monopoly of the American trade as a cause of the war. They tend to overlook the fact that English goods, particularly woollen goods, did reach the Americas in considerable quantities, from Antwerp (modern Belgium) or directly from Spain. Until the death of Mary I[3], some English merchants resident at Seville traded directly with the Indies. If afterward the trade had to pass through the hands of the Spanish merchants, the profits, albeit smaller, were surer, the turnover was quicker, and English merchants were relieved of the risk and expense of the transatlantic voyage. Besides, the Spaniards themselves were excellent customers. They took readily English woollen cloths, woven in part out of Spanish wool, as well as tin, lead, and wheat.

As to the Spanish, the English were their best customers. The English had little interest in American colonial produce except logwood and sugar, and these they bought mostly from the Portuguese, but they took Spanish fruits, 
olives, olive oil, and wine (the English were the most enthusiastic consumers of the Spanish wines). Up to 1585 trade relations provided an argument for peace, not war.

A much more heated debate was the position of the Netherlands. Philip had inherited the Seventeen Provinces[4] from his father, the Emperor Charles V. From the time of Philip's accession the Low Countries had been restless. For nearly twenty years they had been in open revolt, a revolt for which religion was only one of the causes. For the last five years or so, the Spanish, under the leadership of Alexander of Parma, the greatest captain of his century, were steadily winning ground from the rebels, steadily driving them into a corner. The prospect of the Netherlands lying helpless under the feet of a powerful Spanish army, able to block English access to the Continent and to cross the Channel to England's shores in a few hours, was one to alarm even the most peaceably inclined English politicians. It was this prospect which at last persuaded Elizabeth to send the Earl of Leicester[5] with a small English army on a mission to help the Dutch rebels and Francis Drake[6] with a considerable force to the West Indies on an expedition aimed to cripple Spanish finances. It was these provocative acts which led Philip to impose an embargo on English trade with Spain, thus bringing war nearer. Nevertheless, neither sovereign was willing to take the decisive step.

Their reasons for keeping the peace were at least as strong as their reasons for war. One argument for peace with England overrode all others: due to winds and currents, reefs and shoals, the only safe track for Spanish ships on their way north from Spain to Flanders was within sight of the English coast, and the only ports they could seek in an emergency were English ports. It was not mere rhetoric when the Emperor Charles $V$ told his son more than once, "War with all the world, but peace with England." Philip always paid strict attention to what his father had told him.

No ruler of this century was more sensitive to the economic interests of the country than Elizabeth. She knew the importance of an outlet in the Netherlands for the sale of English cloth, on which, after agriculture, the prosperity of her realm depended. If there was a tradition of more than a hundred years of alliance with Spain, the tradition of alliance with Flanders was much older. In Flanders and Holland were the ports not only through which English goods could most cheaply and safely reach the Continent, but from which an invasion of England could be launched most quickly and easily. And on the frontier of Flanders lay France, divided by religious civil wars, but in area, population, productivity, and centralized power was the greatest state in Europe.

There was one tie between Elizabeth and Philip stronger than profitable trade and old alliances. That was the life of Mary Queen of Scots[7]. For nearly twenty years Mary Stuart had been the unwanted 'guest' of her cousin. Since she was a devout Catholic and the next in succession to the English throne, Elizabeth had always been the target of plots by English Catholics who thought the quickest way to restore the Catholic faith would be to shorten the life of Queen Elizabeth. This had led to Mary's closer and closer confinement. But though the Queen's Councillors were convinced of Mary's involvement in these plots, determined to get her executed for high treason, Elizabeth had always intervened to save her cousin's life. Not because she loved her rival, Mary, or because she was convinced of her innocence, but because she knew Philip of Spain would never try to remove her from her throne as long as the most likely result would be the accession to the throne of a woman who was half French by blood, who would promptly present her French relatives with the lordship of both sides of the English Channel. But with each plot the outcry for Mary's life grew stronger, and at last Elizabeth could no longer resist the clamour. In February, 1587, Mary was executed for high treason and the die was cast. As soon as Philip heard the news he began to think seriously of the plan for the invasion of England.

His plans were further delayed by Drake's brilliant raid down the Spanish coast, burning ships in the harbour of Cadiz, but most of the ships burnt had nothing to do with the Armada at all. Drake's raid delayed the sailing of the Armada until the following spring. In February, 1588, the Marquis of Santa Cruz, commander of the invasion fleet, died and was replaced by the Duke of Medina Sidonia, a great nobleman, but a man without military experience. Spanish historians have always held that had Santa Cruz lived and not been replaced the outcome of the campaign might have been very different.

On the other hand, Medina Sidonia, though inexperienced was able to put together a fleet, which was much stronger than what the Marquis of Santa Cruz had been willing to settle for. Probably Spanish historians have blamed Medina Sidonia because he was so ready to blame himself. He was a man of excessive modesty. He felt, and said explicitly, that if someone else had been in command, things might have come out differently. In the Armada campaign, the Duke was willing to assume that since the responsibility was his, the failure was also his. Actually it is hard to see how anyone saddled with King Philip's unworkable plan could have done much better against the odds he had to face.

Spanish historians have been too severe with their admiral but not critical enough of their sovereign. The English commanders, Drake and Hawkins and even the Lord Admiral, Howard, had proposed to blockade the Spanish coast. English historians have condemned the Queen for ignoring their plan. Elizabeth knew that if her navy launched an attack, it would have been decimated and provisions exhausted. The English fleet would have been in no condition to 
face an enemy for weeks, perhaps for months. And the cost would have been staggering. Elizabeth's preference that the battle should be fought in home waters, was a major contribution to English victory. So the battle was fought in the Channel, where the English, due to their knowledge of the local waters and their nearness to fresh supplies and reinforcements, had the best chance of victory.

On July 30, the Armada sailed from Lisbon with 130 ships. Nearly half the fleet were either light ships, or great, clumsy ships for carrying supplies and troops. It was this slow, awkward division which was the greatest handicap to the Armada. Opposing this force, English had 197 ships. Actually, not all of these were involved in action; some of them were supply ships and a good many were incapable of carrying heavy guns and were used mainly for scouting.

The myth of the little English ships and the huge Spanish ones has long since been refuted by naval historians. The English ships-of-the-line were on the whole bigger than their Spanish opponents. This does not hold true for the English second line. The best forty-five of the English armed ships, were certainly not only faster and handier than their opponents but much tougher and more heavily gunned. It is hard to be precise about the relative tonnage and fire power of the fighting ships in the two fleets. However, in comparison with their English adversaries the Spanish were seriously under-gunned. For the English, the most useful guns would not be those which could sink a ship at short range, but those which from a greater distance could cripple the fleeing ships. They planned to fight the Armada, using their greater speed and maneuverability.

This is how the battle was fought. The Spanish fleet would attack if there seemed to be a favourable opportunity, hampered as they were to be throughout the campaign by their clumsy, slow-sailing ships. The Spaniards had already arranged a formation. With remarkable discipline and precision they had formed a crescent toward the enemy. This was a formation calculated to counter the expected English tactics. On the first day the two fleets banged away at each other at long range without doing much damage.

For some hours the wind favoured the Spaniards. The result was a terrific gun battle, by far the biggest and noisiest naval battle the world had ever seen. But the only significant result was that the English supply of gunpowder and cannon balls was nearly exhausted and the Spanish seriously depleted. Neither side could do the other much harm. If they really wanted to sink enemy warships, the closer they fought the better.

Howard began appealing desperately for more powder and cannon balls. If he had been fighting off the coast of Spain, he would have had to let the Armada proceed unhindered. Since he was in the Channel, he got fresh munitions daily, though not as much as he wanted. Nevertheless he was feeling as frustrated as his adversaries. If he had suffered practically no damage from them, he had failed to break their formidable order or impede their steady march up the Channel. The best he could claim was that he had kept the Spanish from landing anywhere on the English coast.

But the Armada plodded on in unbroken order to anchor under the cliffs of Calais. This was the critical moment. By the time the Armada anchored off Calais, the incredible store of cannon balls was almost completely exhausted. There was not nearly enough for another day's battle. Up to this point, in spite of the odds against it, the Armada had accomplished with success its hazardous and tricky mission.

Parma was not ready to come out; he probably never intended to try to come out. The limit to his success in the war in the Netherlands had always been the Dutch command of the coastal waters. In those waters cruised a strong fleet of Dutch boats, not big but heavily gunned. They were waiting to sink Parma's ships as they emerged from their harbours. The Armada could not have prevented the massacre of Parma's flotilla.

This was the fatal flaw in Philip's plan. Parma had hinted to him clearly more than once but Philip had ignored him. Medina Sidonia knew little of Dutch coastal waters and much less of Parma's capabilities at sea. While Medina Sidonia waited at Calais, puzzled by Parma's delay, the English had time to prepare fire ships to dislodge the Armada from its anchorage, and when, after midnight of their second day at anchor, the Spanish saw eight ships moving towards them, spouting flames and fire, they disobeyed their admiral's orders, cut their cables, and ran for the open sea in disorder. This was the first instance of Spanish panic or indiscipline in the whole campaign.

In spite of the panic, Medina Sidonia, who had behaved throughout with admirable courage and judgment, succeeded in rallying and re-forming his fleet and fought with their small arms against the great guns of their foe. But this time the English were coming closer and closer and doing serious damage. Many Spanish ships were badly damaged. Gradually their formation was broken up and it looked as though in another half-hour the whole Spanish fleet might be destroyed. Then a sudden violent wind interrupted the battle and gave the Spaniards a chance to get away into deep water. When the weather cleared, the Armada was back in its old formation and its admiral willing to renew the combat.

The English did not accept the challenge; they, too, had run out of ammunition. They did not realize how badly they had hurt the Armada, and they were a little awed by its unexpected strength and discipline. The English who were 
short of food and water, and worst of all, of beer, and who had had no reply to their pleas for enough supplies and munitions to help them finish the job, turned away, and the Spanish sailed on into the northern seas.

The Spanish were in a worse situation than the English. Almost every ship was leaking. Some had sunk. Some had run for the German coast and were never seen again. Casualties were very heavy. There were not only no cannon balls and gunpowder, but little food and alarmingly little water. Nevertheless, the Council of War decided after much debate that if the wind changed they would turn and try to fight their way back through the Channel. But if the wind held, they agreed, they would have to try to get home around the north of Ireland. When the fleet turned south, it was scattered by storms and strong winds. Some commanders made, against orders, for the Irish coast. Of those, all but one - perhaps as many as seventeen - were lost, the heaviest losses of the campaign. Of those who obeyed the Admiral, though they suffered terribly, most, perhaps all got home.

The disappearance of the Armada into the northern seas scarcely reduced the tension felt in England ever since rumours began to spread of the imminent invasion. When Elizabeth went down to Tilbury, ten days after the decisive battle of Gravelines, her Principal Secretary was hearing from her captains not of their triumph but of their dismay that their chosen tactics had not worked, so that the enemy fleet was still largely intact and likely to come back at any moment. In consequence, mobilization by land and sea had to be kept up. It was not until news began to come in of Spanish shipwrecks around Ireland (the shipwrecks which prompted the myth of the destruction of the Armada in a terrible tempest) that the English realized that there would be no more danger of invasion this year, and that they had, indeed, won something like a victory.

When, on the thirtieth anniversary of her reign, the Queen went to St. Paul's, where the captured Spanish banners had been hung up, the people hailed her as the victorious champion of her kingdom and their faith. The next few years were probably those of Elizabeth's greatest popularity and this was almost certainly due to her having come forward at last as the open champion of the Protestant cause, to her gallant conduct in the months of danger, and to the victory, by divine intervention that almost everyone believed, which crowned her efforts. A good many Englishmen had doubted that the Spanish could ever be beaten. Now they knew that they could. They understood, however, that England had not won a war, only the first battle in a war in which there might be many more battles. England was braced for the struggle. The grave doubts that had arisen about English naval armament and tactics, the unprecedented expenses of the long mobilization, and the dubious prospects of next year's campaign all served to dampen any excess of patriotic optimism. A year later the humiliating repulse of Drake's attempted invasion of Portugal made optimism even less appropriate.

The Spanish losses were not so bad as is often said. Medina Sidonia brought home almost two-thirds of the ships that had followed him from Corunna. But there was no doubt that the fleet which came home had been beaten. On most ships the mortality, from battle and disease, was around 50 per cent. And more than half the ships that struggled back home were so battered by English guns and Atlantic waves that they were not worth repairing. Philip began to realize that he would have to build a new navy.

If the new Spanish navy was not able to command the seas, if it could not stop raids on Spain and on the West Indies, it could prevent any blockade of the Spanish coast. If the Spanish navy could not dominate the Channel, it could threaten it. Drake and Hawkins, for instance, felt sure that once war was declared they could quickly bring King Philip to his knees by cutting off his supplies of gold and silver from America. No idea could have pleased Queen Elizabeth more than fighting an enemy with his own money, and repeatedly, throughout the long war, her captains at sea tried to put this idea into effect.

In 1596 the Spanish seized Calais, and Spanish corsairs plundered and burned English ships sometimes in plain sight of the English coast. But the Spanish navy was never able to mount another invasion of England, or even to hold a base in Ireland. The war dragged on for more than fifteen years, longer than either King Philip or Queen Elizabeth would live.

Historians are fond of generalizations about the defeat of the Spanish Armada. One of them, that the victory of 1588 "transferred the command of the seas from Spain to England," could scarcely be wider of the mark. Another generalization is that the defeat of the Spanish Armada began the rise of the British and the decline of the Spanish empire, but it is the complete reverse of what actually happened. By 1604, the Spanish empire was as imposing in extent as it had ever been. And the British empire was still to be founded.

Another popular generalization about the defeat of the Spanish Armada is that the event produced in England a mood of buoyant optimism, which somehow stimulated the flowering of Elizabethan literature. Historians find it irrelevant to ask whether Napoleon's years of glory produced a greater literature in France than the decades of defeat and pessimism which followed. 
It is true that in the years before the Armada campaign there were in England men of extraordinary talent, such as Spenser, Shakespeare, and Marlowe, who in the decade after 1588 produced some of their finest work. But it would be impossible to argue that the events of 1588 encouraged these productions and it is surprising how little the theme of the defeat of the Armada itself contributed to them. If the campaign of 1588 did anything to increase the confidence or relieve the anxiety, that still remains to be proved.

One Tudor historian has suggested that the real importance of the year 1588 in English history is neither in international relations nor in cultural history but in developments in domestic politics. The year 1588, he insinuates, is the watershed between Tudor and Stuart times. After 1589, Elizabeth, though her people still loved her, had passed the peak of her popularity and prestige. It was becoming clear that she was increasingly alone, beginning to be out of touch with her times, and she had no one to rely on except the cold and sly Robert Cecil[8]. As the result of fifteen years of war with Spain, Elizabeth left to her successor a Crown politically weaker than it had been since the mid-fifteenth century and financially almost as near bankruptcy as that which she had inherited. So perhaps it might be said that the war, whose first act was the defeat of the Spanish Armada, resulted in the Puritan Revolution, and the sequence of events, which began with the execution of Mary Queen of Scots and ended in the execution of her grandson, Charles I[9].

\section{Conclusion}

The next few years were probably those of Elizabeth's greatest popularity and this was almost certainly due to her having come forward at last as the open champion of the Protestant cause, to her gallant conduct in the months of danger, and to the victory, by divine intervention that almost everyone believed, which crowned her efforts. A good many Englishmen had doubted that the Spanish could ever be beaten. Now they knew that they could. They understood, however, that England had not won a war, only the first battle in a war in which there might be many more battles. England was braced for the struggle. After 1589, Elizabeth, though her people still loved her, had passed the peak of her popularity and prestige. It was becoming clear that she was increasingly alone, beginning to be out of touch with her times, and she had no one to rely on. As the result of fifteen years of war with Spain, Elizabeth left to her successor a Crown politically weaker than it had been since the mid-fifteenth century and financially almost as near bankruptcy as that which she had inherited.

\section{References}

Queen Elizabeth and the Spanish Armada, Frances Winwar, 1954

The Spanish Armada, Colin Martin \& Geoffrey Parker, 2002

Armada 1588: The Spanish Assault on England, John Barratt, 2005

The Armada, Garrett Mattingly, 2005

England and the Spanish Armada, James McDermott, 2005

The Spanish Armada: The Great Enterprise against England 1588, John Barratt, 2009 
